\title{
Chapter 31 \\ The Use of GIS and Digital Elevation Model in Digital Soil Mapping - A Case Study from São Paulo, Brazil
}

\author{
G.S. Valladares and M.C. Hott
}

\begin{abstract}
This paper applied pedological mapping in an experimental center of "APTA-Frutas" in Jundiaí, São Paulo, Brazil, using morphometric parameters and GIS tools. The aim of this work was to obtain a preliminary legend of a soil map and to compare the preliminary map with maps made by the traditional soil survey methods. The area has 59 hectares and is located at a mountainous relief in the Atlantic Plateau. The original soil map of this area was made at 1:10 000. A digital elevation model (DEM) was generated with $4 \mathrm{~m}$ spatial resolution based on a topographical map at 1:10 000 scale, where the level curves are equidistant at $5 \mathrm{~m}$. Based on the DEM we generated altitude, curvature and slope maps. In order to map the hydromorphic soils it was generated a buffer around the hydrography. We also calculated frequency distribution graphics of altitude, curvature and slope maps. After the interpretation of the frequency distribution, we defined classes to predict the soils types. The curvature map was divided into two class intervals $(<$ or $=0$ and $>0)$, the altitude map was divided into four class intervals (690-703, 704-714, 715-730, and 731-757 m), and the slope map was divided into four class intervals $(0-9,10-19,20-44$, and 45-72\%). The maps were reclassified and converted to shape files. The shape files were intersected with the others to generate the final preliminary soil map. The methodology was adequate for the preliminary mapping of some types of soils.
\end{abstract}

\subsection{Introduction}

This paper applied a pedological mapping methodology (digital soil mapping), in an experimental center of APTA-Frutas (São Paulo State Agribusiness Technology Agency-Fruits) in Jundiaí Municipality, SP, Brazil, using morphometric parameters and GIS (Geographic Information System) tools.

G.S. Valladares

EMBRAPA National Satellite Monitoring Research Center, Campinas, SP, Brazil 13070-115

e-mail: gustavo@cnpm.embrapa.br 
The digital elevation models (DEM) (see also Chapter 15) provide information on topography, and derivative products, such as slope that through histograms or reference areas allows to compare with traditional soil map (Lagacherie et al., 1995), as well as to make rules that will be applied to a DEM (McBratney et al., 2003). Both reference areas and histograms need a wide knowledge of the study area to delineate samples (Lagacherie et al., 2001) or to classify soils.

The local landform or relief, represented through DEM, has a major impact on soils by controlling water and sediment movements (McKenzie and Ryan, 1999), together with other factors, such as parent rock.

The aim of our study was to propose a methodology to obtain a preliminary legend of a soil map, which may guide the pedologists in their fieldwork and augment their understanding of the soil-landscape relationship. Previous studies have investigated this topic (Arcoverde et al., 2005; Mühlethaler et al., 2005) and the focus of our work was to compare the preliminary map with the traditional soil maps and to provide an alternative to support decision-making in soil survey planning management.

\subsection{Material and Methods}

The study area has 59 hectares and is located at Jundiaí, approximately $75 \mathrm{~km}$ northwest of São Paulo, Brazil, in a mountainous relief in the Atlantic Plateau (Fig. 31.1). The study area receives $1,409 \mathrm{~mm}$ of rain per year with the majority falling between October and March. The land use and land cover are predominantly apple, vineyard, peach, citrus and natural vegetation (Atlantic Forest).

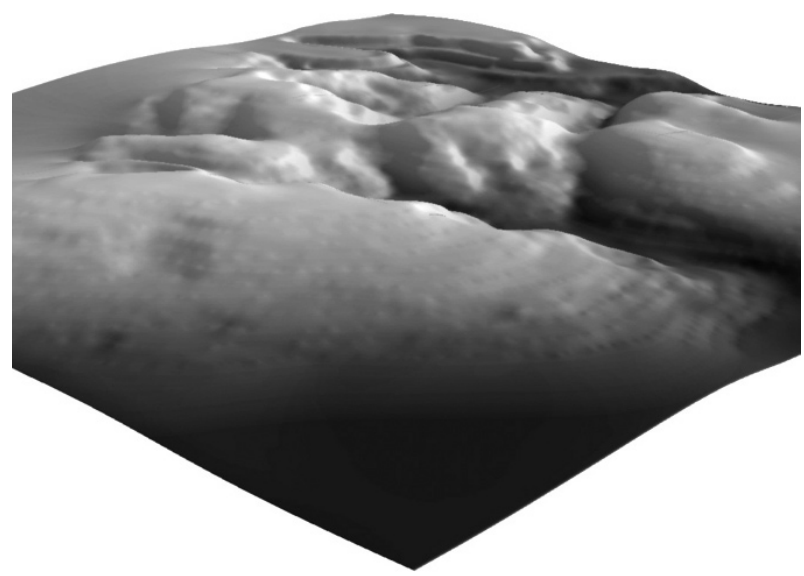

Fig. 31.1 Illustration of the DEM of CAPTA-Frutas, Jundiaí, SP, Brazil in 3D projection 
The original soil map of the area was made at 1:10 000 scale (Valadares et al., 1971). It was digitalized and inserted in a GIS. The map's legend was converted to World Reference Base for Soil Resources -WRB (ISSS, 1998).

Using the TOPOGRID function with ArcInfo Workstation GIS available in ArcGIS 9.0 package (ESRI, 2004), a digital elevation model (DEM) with $4 \mathrm{~m}$ of spatial resolution (Fig. 31.2a) was generated, based on the 1:10 000 topographical map (Melo and Lombardi Neto, 1999), where the level curves are equidistant at $5 \mathrm{~m}$. Based on the DEM, we generated derivated maps with ArcGIS software, like altitude, curvature and slope maps (Fig. 31.2a, b and c).

In order to map hydromorphic soils, we made a buffer with 7 meters around the hydrography (Fig. 31.5a). We have also made frequency distribution graphics representing altitude, curvature and slope maps. We defined classes to predict the

Fig. 31.2 Maps derived from DEM of CAPTA-Frutas, Jundiaí, SP, Brazil. (a) altitude with level curves, hydrography and buffer; (b) curvature; (c) slope

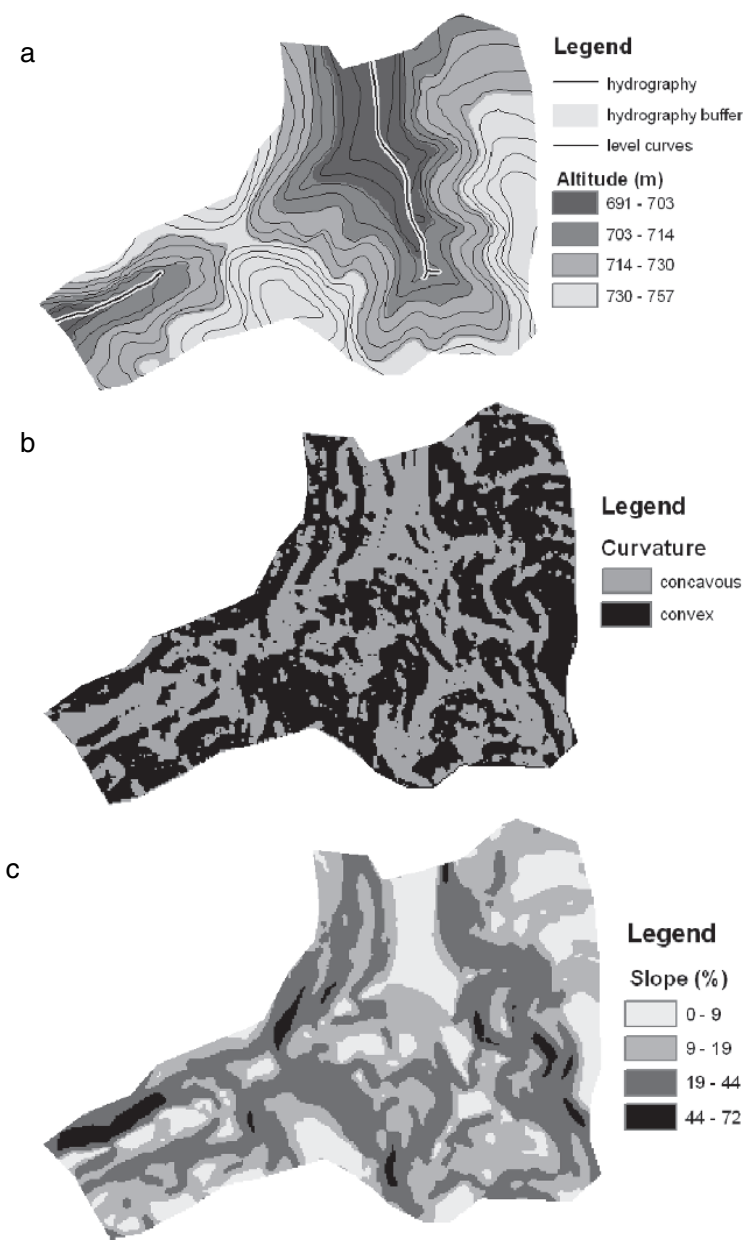


soils types. It was made after visual interpretation of natural breaks in the frequency distribution.

The joint interpretation of all the maps and the INTERSECT function were used to generate the preliminary soil map. The INTERSECT function was applied between the altitude and curvature maps to generated a first version of the preliminary soil map (psoil_1). Then psoil_1 was intersected with the slope map producing a second version of the preliminary soil map (psoil_2). In the last step, the p_soil_2 was intersected with the hydrographic buffer to generate the final preliminary soil map (see also Sections 19.2 and 34.2, using parameters derived from digital models).

\subsection{Results and Discussion}

The curvature map was divided into two classes in the study area, concave and con$\operatorname{vex}(<$ or $=0$ and $>0)$, as the mountainous relief plain ground (near 0$)$ is minimally representative. In the concave areas, soils like Dystric Gleysols or Orthic Acrisols are common, while Dystric Cambisols and Xanthic Ferralsols are predominant in the convex areas.

The altitude map varies from 690 to $757 \mathrm{~m}$ and was divided into four class intervals (690-703, 704-714, 715-730, and 731-757 m). Fig. 31.3a shows the frequency distribution for altitude. Within the class "690-703 m" all the Dystric Gleysols and a part of the Orthic Acrisols occur, while in the class "higher than $730 \mathrm{~m}$ " occur the Dystric Cambisols and the Xanthic Ferralsols. In both intermediate classes (704-714 and 715-730 m) the Orthic Acrisols, Dystric Cambisols and the Xanthic Ferralsols are common. It is not possible to differentiate exactly the soil types using the altitude map.

In the study area, slopes vary from 0 to $72 \%$. The slopes were divided into four class intervals $(0-9,10-19,20-44$, and 45-72\%). Fig. 31.3b shows the frequency distribution for the slope classes. Table 31.1 represents a matrix of soil types and the altitude and slope class intervals, without considering curvature.

The maps were reclassified and converted to shape files. In the shape file format, the INTERSECT function was applied to the maps (Fig. 31.4). Firstly, a map
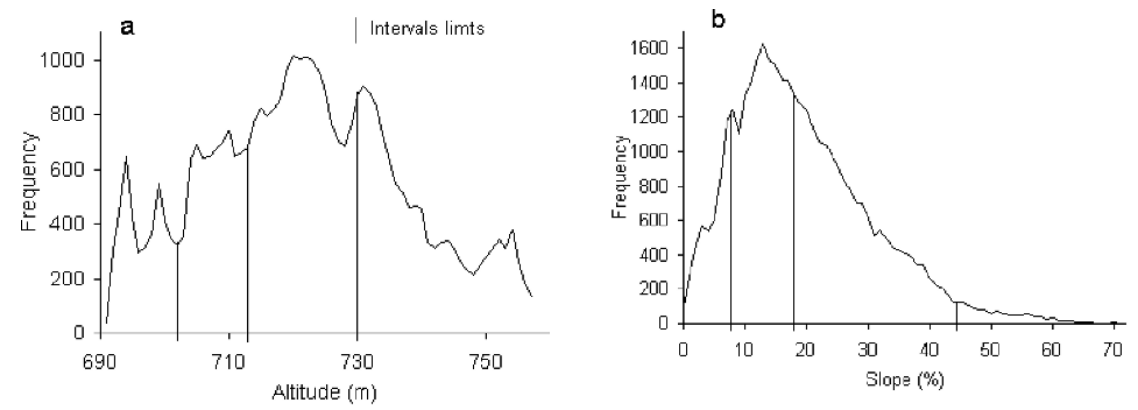

Fig. 31.3 Frequency distribution for altitude (a) and slope (b) 
Table 31.1 Soil types based on altitude and slope from CAPTA-Frutas, Jundiaí, SP

\begin{tabular}{lllll}
\hline Slope classes (\%) & \multicolumn{4}{l}{ Altitude classes $(\mathrm{m})$} \\
\cline { 2 - 5 } & $690-703$ & $704-714$ & $715-730$ & $731-757$ \\
\hline $0-9$ & Dystric Gleysols & Orthic Acrisols & Xanthic Ferralsols & Xanthic Ferralsols \\
$10-19$ & Orthic Acrisols & Orthic Acrisols & Orthic Acrisols & Orthic Acrisols \\
$20-44$ & Orthic Acrisols & Orthic Acrisols & Orthic Acrisols & Orthic Acrisols \\
$45-72$ & Orthic Acrisols & Orthic Acrisols & Orthic Acrisols & Orthic Acrisols \\
\hline
\end{tabular}

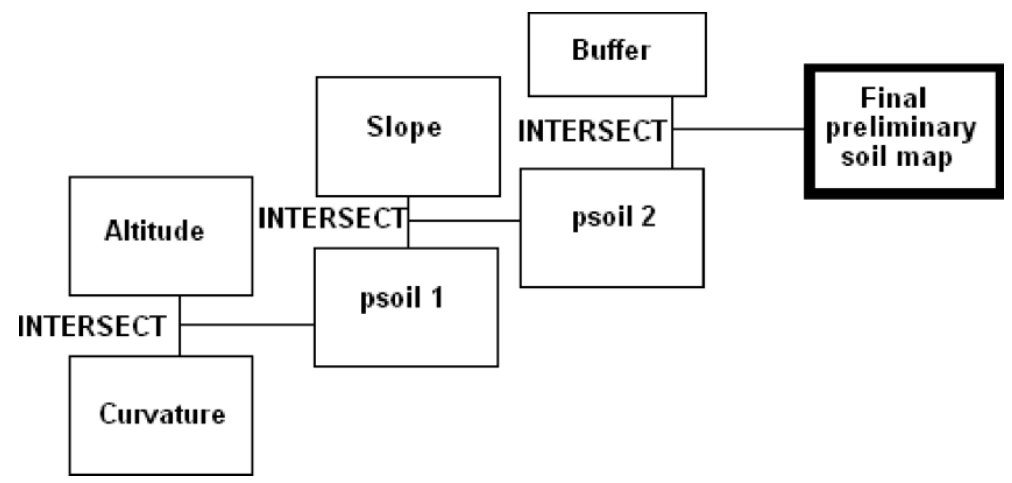

Fig. 31.4 Simplified flowchart for elaboration of the final preliminary soil map

(psoil_1) was generated with the intersection between the altitude and curvature shape files. This new shape file (psoil_1) was intersected with the slope shape file, generating a second version (psoil_2). In the last step, the psoil_2 shape file was intersected with the hydrographic buffer shape file to generate the final preliminary soil map (Fig. 31.5a). Table 31.2 shows the interpretation of the soil types after finishing all the maps' intersections.

The original soil map (Fig. 31.5b) was combined with the digital soil map using the intersect function. For the Dystric Cambisol, the equivalence area was 76\%, and for the Dystric Gleysol the equivalence area was 74\%. For the Orthic Acrisol, the equivalence was 55\% and in the Xanthic Ferralsol the equivalence area was only 15\%. The Xanthic Ferralsol was confused with the Dystric Cambisol, because both occur at the same altitude and have similar slope and curvature characteristics, which proved to be a limitation in the proposed approach. Table 31.3 shows that $59 \%$ of the area with the Xanthic Ferralsols were classified in the digital soil map as Dystric Cambisols soil and 26\% as Orthic Acrisols soil.

In the lower altitude terraces with smaller declivities and concave forms near the streams, the wetlands with hydromorphic soils predominate, and it was classified as Dystric Gleysols (Fig. 31.5a). Comparing Fig. 31.5a and 31.5b, the Dystric Gleysols were overestimated in the northern part, where it was confused with the Orthic Acrisols soil area. Table 31.3 shows that $20 \%$ of the Dystric Gleysols area was classified as Orthic Acrisols and 6\% as Dystric Cambisols in the preliminary digital soil map (see also example in Fig. 19.1). 


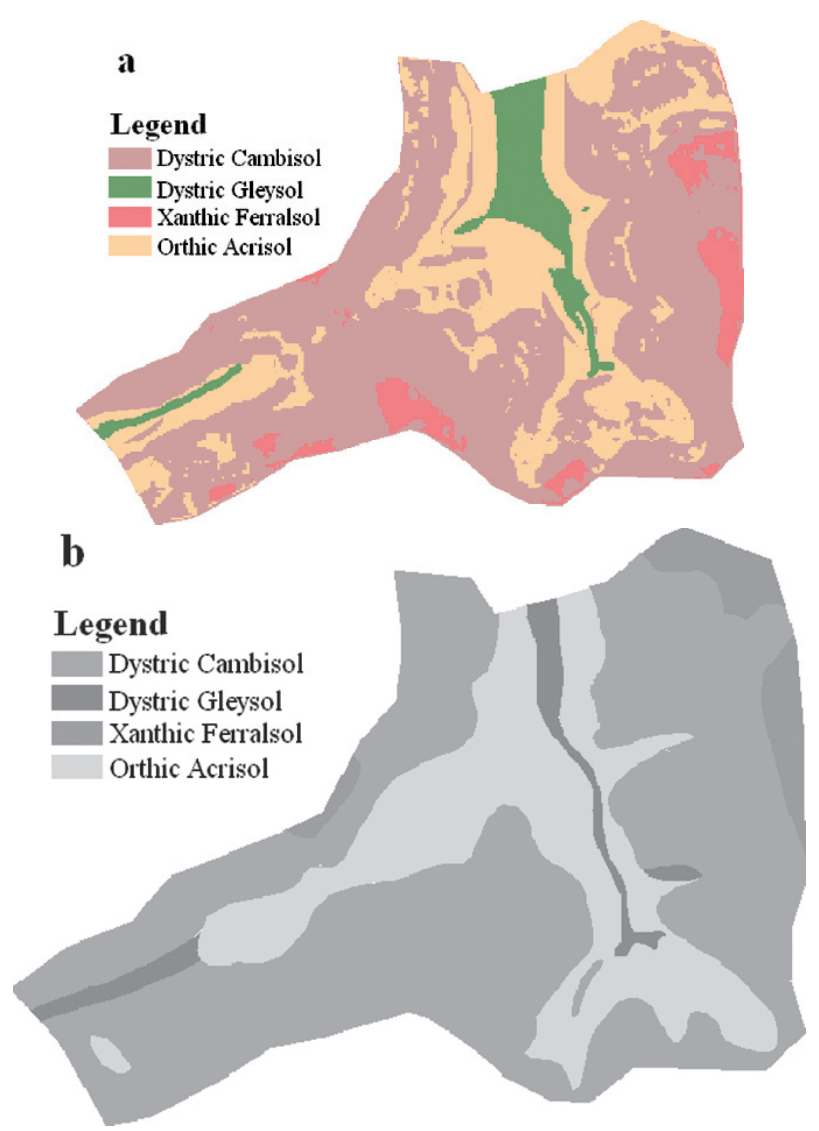

Fig. 31.5 Preliminary digital soil map derived from DEM (a), and final soil map elaborated by traditional soil mapping (b) of CAPTA-Frutas, Jundiaí, SP, Brazil (See also Plate 42 in the Colour Plate Section)

The Orthic Acrisols are located in the lower part of the slope. These area had previously been underestimated (Fig. 31.5a and 31.5b), where they had been confused with Dystric Cambisols and Dystric Gleysols. Table 31.3 shows that $31 \%$ of the Orthic Acrisols area was classified as Dystric Cambisols and 14\% as Dystric Gleysols.

The Dystric Cambisols predominated in the study area and were located in the upperslopes and in the higher parts of the landscape. Fig. 31.5 represents the results for this soil type. Table 31.3 shows that $17 \%$ of the Dystric Cambisols area was classified as Orthic Acrisols and 7\% as Xanthic Ferralsols. 
Table 31.2 Soil types defined to produce the preliminary digital soil map after combinations between maps buffer around the hydrograph, curvature, altitude, and slope

\begin{tabular}{|c|c|}
\hline $\begin{array}{l}\text { Soil Types in Preliminary } \\
\text { Digital Soil Map }\end{array}$ & Combinations hydrography buffer + curvature + altitude + slope \\
\hline Dystric Gleysol & $\begin{array}{l}\text { all sites with hydrography buffer, } \\
\text { no buffer }+ \text { concave }+(609-703 \mathrm{~m})+(0-9 \%) \text {, } \\
\text { no buffer }+ \text { convex }+(609-703 \mathrm{~m})+(0-9 \%) \\
\text { no buffer }+ \text { concave }+(704-714 \mathrm{~m})+(0-9 \%), \\
\text { no buffer }+ \text { convex }+(704-714 \mathrm{~m})+(0-9 \%), \\
\text { no buffer }+ \text { concave }+(609-703 \mathrm{~m})+(10-19 \%) \text {, } \\
\text { no buffer }+ \text { convex }+(609-703 \mathrm{~m})+(10-19 \%) \text {, }\end{array}$ \\
\hline Orthic Acrisol & $\begin{array}{l}\text { no buffer }+ \text { concave }+(609-703 \mathrm{~m})+(>19 \%), \\
\text { no buffer }+ \text { convex }+(609-703 \mathrm{~m})+(>19 \%), \\
\text { no buffer }+ \text { concave }+(704-714 \mathrm{~m})+(10-19 \%), \\
\text { no buffer }+ \text { concave }+(715-730 \mathrm{~m})+(10-19 \%), \\
\text { no buffer }+ \text { concave }+(715-730 \mathrm{~m})+(0-9 \%) \\
\text { no buffer }+ \text { concave }+(704-714 \mathrm{~m})+(>19 \%), \\
\text { no buffer }+ \text { convex }+(704-714 \mathrm{~m})+(>19 \%), \\
\text { no buffer }+ \text { concave }+(715-730 \mathrm{~m})+(>19 \%),\end{array}$ \\
\hline Dystric Cambisol & $\begin{array}{l}\text { no buffer }+ \text { convex }+(715-730 \mathrm{~m})+(>19 \%), \\
\text { no buffer }+ \text { concave }+(>730 \mathrm{~m})+(10-19 \%), \\
\text { no buffer }+ \text { convex }+(>730 \mathrm{~m})+(10-19 \%), \\
\text { no buffer }+ \text { concave }+(>730 \mathrm{~m})+(>19 \%), \\
\text { no buffer }+ \text { convex }+(>730 \mathrm{~m})+(>19 \%) \\
\text { no buffer }+ \text { convex }+(704-714 \mathrm{~m})+(10-19 \%), \\
\text { no buffer }+ \text { convex }+(715-730 \mathrm{~m})+(>19 \%),\end{array}$ \\
\hline Xanthic Ferralsol & $\begin{array}{l}\text { no buffer }+ \text { convex }+(715-730 \mathrm{~m})+(0-9 \%) \\
\text { no buffer }+ \text { concave }+(>730 \mathrm{~m})+(0-9 \%) \\
\text { no buffer }+ \text { convex }+(>730 \mathrm{~m})+(0-9 \%)\end{array}$ \\
\hline
\end{tabular}

Table 31.3 Soil types correspondence area (\%) for traditional and preliminary soils maps from CAPTA-Frutas, Jundiaí, SP

\begin{tabular}{lrrrr}
\hline & \multicolumn{2}{l}{ Traditional Soil Map } & \\
\cline { 2 - 5 } Preliminary & Dystric Cambisol & Dystric Gleisol & Xanthic Ferralsol & Orthic Acrisol \\
Digital Soil Map & & 6 & 59 & 31 \\
\hline Dystric Cambisol & 76 & 74 & 0 & 14 \\
Dystric Gleysol & 0 & 0 & 15 & 0 \\
Xanthic Ferralsol & 7 & 20 & 26 & 55 \\
Orthic Acrisol & 17 & 100 & 100 & 100 \\
Total & 100 & & &
\end{tabular}

\subsection{Conclusions}

The proposed methodology was adequate to identify some types of soils using GIS, and showed the importance of relief in the Atlantic Plateau soils' formation. In order to produce a detailed soil map using this methodology, additional fieldwork is 
necessary. For the Dystric Cambisol, the Dystric Gleysol, the Orthic Acrisol, and the Xanthic Ferralsol the equivalence area was respectively, 76\%, 74\%, 55\% and $15 \%$.

The Dystric Cambisols and the Xanthic Ferralsols predominated in the upperslopes and in the higher parts of the landscape. In the lower altitude terraces, which have smaller declivities and concave forms near the streams, predominate the wetlands with hydromorphic soils, classified as Dystric Gleysols. The Orthic Acrisols are located in the lower part of the slope.

Soils are function of five formation factors: parent rock, relief, vegetation, climate and time. In this study we considered only the relief factor. For large areas with lesser scales, other soil formation factors may be included in the analysis, with the purpose of obtaining satisfactory results.

\section{References}

Arcoverde, G.F.B., Borges, M.E.S., Martins, E.S., Ramos, V.M., Guimarães, R.F., Carvalho Junior, O.A., Gomes, R.A.T., 2005. Mapeamento pedológico em relevos cársticos a partir da análise morfométrica. XII Simpósio Brasileiro de Sensoriamento Remoto. INPE, Goiânia, Brazil, pp. 1725-1732.

Environmental Systems Research Institute (ESRI). 2004. ArcInfo 9.0. Redlands, CA.

ISSS International Society of Soil Science Working Group, 1998. World Reference Base for Soil Resources. ISRIC, FAO, Rome.

Melo, A.R., Lombardi Neto, F., 1999. Planejamento Agroambiental do Centro Avançado de Pesquisa do Agronegócio de Frutas. IAC/APTA, Campinas.

Mühlethaler, B., Ramos, V.M., Carvalho Junior, O.A., Guimarães, R.F, Bettiol, G.M., Gomes, R.A.T., Martins, E.S., Reatto, A., 2005. Avaliação do uso da morfometria como suporte para a elaboração de mapa pedológico na bacia do Ribeirão da Pedreira - DF. XII Simpósio Brasileiro de Sensoriamento Remoto. INPE, Goiânia, Brazil, pp. 3167-3174.

Lagacherie, P., Legros, J.P., Burrough, P.A., 1995. A soil survey procedure using the knowledge of soil pattern established on a previously mapped reference area. Geoderma 65, 283-301.

Lagacherie, P. Robbez-Masson, J.M., Nguyen-The, N., Barthès, J.P., 2001. Mapping of reference area representativity using a mathematical soilscape distance. Geoderma 101, 105-118.

McBratney, A.B., Mendonça Santos, M.L., Minasny, B., 2003. On digital soil mapping. Geoderma 117, 3-52.

McKenzie, N.J., Ryan, P.J., 1999. Spatial prediction of soil properties using environmental correlation. Geoderma 89, 67-94.

Valadares, J., Lepsch, I.F., Küpper, A., 1971. Levantamento pedológico detalhado da Estação Experimental de Jundiaí, SP. Bragantia 30, 337-386. 